\title{
Endophytic fungi in roots of native orchids of rupestrian grasslands (campos rupestres) in Serra do Cipó, Brazil
}

\author{
Letícia Miranda ${ }^{1,2, *}$ (D), Marlon Corrêa Pereira ${ }^{1, *}$ (D), Tomás Gomes Reis Veloso ${ }^{2}$ (D), Natália \\ Tartarine $^{1}$ (iD), Samira Barcelos Gontijo de Carvalho' ${ }^{1}$ (i) \& Maria Catarina Megumi Kasuya ${ }^{2}$ \\ 'Biological Science and Health Institute, Rio Paranaíba Campus, Federal University of Viçosa, Rodovia MG 230 Km 7 . \\ 38810-000 Rio Paranaíba/MG, Brazil. \\ 2Department of Microbiology, Federal University of Viçosa, Av. Peter Henry Rolfs, s/n, Campus Universitário, 36570-900 Viçosa/MG, Brazil. \\ *leticia.miranda2@ufv.br, marlon.pereira@ufv.br
}

\begin{abstract}
Root endophytic fungi are essential to the life cycle of orchids. Many of them act as growth promoters of the host plant and mycorrhizal endophytes are indispensable to seed germination. This study aimed to evaluate the cultivable endophytic fungal richness of five native orchids of rupestrian grasslands (campos rupestres) in Serra do Cipó, Brazil. Healthy roots were sampled and the endophytes isolated, from which total DNA was extracted and the Internal Transcribed Spacer (ITS) region amplified and sequenced. Analysis of 32 fungal sequences permitted the identification of 25 species of the phyla Ascomycota and Basidiomycota. Nine isolates belonged to the Basidiomycota genera Sebacina Tul. \& C. Tul. and Tulasnella J. Schröt., which contain important mycorrhizal endophytes of orchids. Same fungal species were obtained from different orchids growing on distinct substrates. Fungal molecular identification indicates high endophyte richness supporting the life cycle of orchids in rupestrian grasslands.
\end{abstract}

Keywords: Endemic orchids, Endophytes, Mycorrhizal fungi.

RESUMO - Fungos endofíticos radiculares são essenciais para o ciclo de vida das orquídeas. Muitos deles atuam como promotores de crescimento da planta hospedeira e os endófitos micorrízicos são indispensáveis a germinação de sementes. Este estudo objetivou avaliar a riqueza de fungos endofíticos cultiváveis de cinco orquídeas nativas de Campos Rupestres na Serra do Cipó, Brasil. Raízes saudáveis foram amostradas e os endófitos isolados. Cada isolado teve seu DNA total extraído e a região ITS (Internal Transcribed Spacer) amplificada e sequenciada. A análise de 32 sequências fúngicas permitiram a identificação de 25 espécies pertencentes aos filos Ascomycota e Basidiomycota. Nove isolados pertenciam aos gêneros Sebacina Tul. \& C. Tul. and Tulasnella J. Schröt. do filo Basidiomycota, que são importantes gêneros de fungos micorrízicos de orquídeas. A mesma espécie fúngica foi obtida de diferentes orquídeas crescendo em substratos distintos. A identificação molecular dos fungos indicou alta riqueza de endófitos sustentando o ciclo de vida das orquídeas em campos rupestres.

Palavras chave: Endófitos, Fungo micorrízico, Orquídea endêmica.

\section{INTRODUCTION}

Orchidaceae is one of the largest botanical families with an estimated number of more than 27,000 species (Jones 2006, The Plant List 2020). The greatest importance of these plants is the ornamental potential of their flowers, which are highly diverse in size and color combinations in colorful inflorescences (Cardoso \& Israel 2005), making the family of great economic value. As a result, several native species are highly threatened by predatory collection and illegal trade, in addition to the destruction of their natural environment and climate change (Fay 2018).

In their natural environment, orchids associate with endophytic microorganisms, mainly fungi and bacteria that live inside plants and grow inside their tissues, without causing symptoms of disease (Azevedo 1998, Bayman $\&$ Otero 2006). Most endophytes bring benefits to plant development and the association can, in many cases, be considered mutualistic (Bayman \& Otero 2006, Dearnaley et al. 2012). Even though they are observed in different parts of the plant, fungal root endophytes have gained prominence due their role in promoting orchid growth and the dependence of seed germination on the interaction with mycorrhizal endophytes (Bayman \& Otero 2006, Ma et al. 2015, Dearnaley et al. 2017).

Some endophytic fungi establish mutualistic symbioses with orchids, referred to as orchid mycorrhizal associations (OMAs), and are found in roots of adult plants, thus the term "mycorrhiza" meaning "fungus-root" (from the Greek mykes $=$ fungus and rhiza $=$ root $)($ Antoniolli \& Kaminski 1991, Smith \& Read 2008, Yeh et al. 2019). OMAs are characterized by the presence of pelotons, which are mycorrhizal fungal hyphae colonizing inside compatible cells (Peterson et al. 2004, Dearnaley et al. 2017). Interaction with mycorrhizal fungi is essential for orchid seed germination (Peterson et al. 2004, Yeh et al. 
2019). Since orchid species produce seeds that are extremely small and devoid of reserve tissue, seeds depend on embryo basal cell infection and colonization by mycorrhizal fungi to obtain the simple sugars and nutrients required for development through peloton digestion (Dearnaley et al. 2012, Kuga et al. 2014, McCormick et al. 2016). This metabolic strategy, called mycoheterotrophy, continues until the formation of the first leaf and the beginning of the seedling phase (Dearnaley et al. 2012).

The colonization of the first roots of seedlings is confirmed by the presence of pelotons in cortical cells (Peterson et al. 2004). During this phase, the seedling can interact with the same species of mycorrhizal fungus or other species of mycorrhizal fungi, as well as recruit some non-mycorrhizal endophytes (Smith \& Read 2008, Rasmussen et al. 2015). Seedlings and adult individuals of chlorophyllous orchids can have a mixed biomass carbon source (mixoheterotrophic metabolism), part coming from atmospheric carbon and part from fungal carbon (Selosse et al. 2006). At this stage, the digestion of pelotons in the roots has the important function of providing or enhancing orchid uptake of organic and inorganic nutrients (Smith \& Read 2008, Yeh et al. 2019). In achlorophyllous orchids, however, digestion by fungal hyphae is the main route of obtaining carbon as well as nutrients (Dearneley et al. 2012, 2017).

A great diversity of endophytic fungi has been estimated by obtaining pure cultures from healthy roots of orchids sampled in their natural habitats and the identification of such endophytes has been an important source of information (Boldrini et al. 2010, Shah et al. 2019). The cultivation of isolates allows the interaction between plant and endophyte to be studied by in vitro fungal inoculation of seeds and seedlings, such as in experiments of seed germination (Pereira et al. 2011, 2015, Valadares et al. 2012) and seedling growth promotion (Shah et al. 2019), for example.

With the increase in predatory collection of orchids and the destruction of their natural habitat, the need for conservational strategies for them in their natural environment has become evident, especially for those that are endemic and/or at risk of extinction (Fay 2018). For this reason, it is extremely important to identify the richness of fungi that naturally interact with orchids, particularly for the reintroduction of these orchids in their natural environment. Therefore, the present work aimed to evaluate the richness of cultivable endophytic fungi associated with the roots of five orchid species that occur in rupestrian grasslands (campos rupestres) rock outcrop areas of Serra do Cipó, Brazil. The identification of endophytic fungal isolates will not only make it possible to assess the fungal richness on the roots of these orchid species, but will also document part of the fungal community interacting with them.

\section{MATERIAL AND METHODS}

\section{Collection}

The study site was in Serra do Cipó National Park, an area that belongs to the Cerrado Biome (Brazilian savanna). Serra do Cipó is located in the southern portion of Cadeia do Espinhaço in the state of Minas Gerais, Brazil (Abreu \& Garcia 2005). The studied orchids were Cattleya brevipedunculata (Cogn.) Fowl, Epidendrum saxatile Lindl., Epidendrum secundum Jacq., Grobya cipoensis F. Barros \& Lourenço, and Pleurothallis teres Lindl. All of which are native to Serra do Cipó, with $G$. cipoensis being endemic to this mountain range and $C$. brevipedunculata endemic to the state of Minas Gerais. The studied orchids were located on two rock outcrop areas with different habitats, but both with a predominance of species of Vellozia (Tab. 1). Grobya cipoensis and $C$. brevipedunculata are epiphytes and grow on Vellozia gigantea N.L. Menezes \& Mello-Silva, while Epidendrum saxatile is also epiphyte but grows on Vellozia piresiana L.B.S. Epidendrum spp. and P. teres are saxicolous and grow in organic matter accumulated in rock fractures or on the edges of the outcrop (Tab. 1).

Three to five individuals were selected for each species. Samples consisted of entire individuals when the plants were of small size or when roots were well adhered to the substrate. In other cases, 10 to 15 root fragments were sampled per individual. The samples were packed in plastic bags and transported in a thermal bag to the Microbial Ecology Laboratory (Federal University of Viçosa, Rio Paranaíba Campus), where they were stored at $4{ }^{\circ} \mathrm{C}$ until isolation.

\section{Isolation of endophytic fungi}

The roots were washed in running water and superficially disinfected in a series of immersions in $70 \%$ ethanol for 1 min and $0.5 \%$ sodium hypochlorite for $5 \mathrm{~min}$, followed by three washes in sterile deionized water (Pereira et al. 2005). The roots were then aseptically sectioned transversely into fragments under a magnifying glass. Mycorrhizal colonization was confirmed by the presence of pelotons in cortical tissue. Fragments containing pelotons had their velamen removed and the colonized cortex portion was transferred to Petri dishes containing PDA medium (Potato Dextrose Agar, HIMEDIA). On average, five portions of cortex were transferred to each plate and five plates per plant were inoculated. The plates were then incubated at $25{ }^{\circ} \mathrm{C}$ and monitored for 15 days. When mycelium was observed growing from the root fragments, they were transferred to another plate containing PDA medium. Successive subcultures were performed to obtain pure culture. The cultural characteristics of fungal isolates were evaluated in PDA medium considering color (front and back of the colony), aspect and aerial mycelium (presence or absence). 
Table 1. Species, habitat, collection site and sample codes of native orchids whose roots were sampled in rupestrian grasslands rock outcrop areas of Serra do Cipó, Brazil

\begin{tabular}{lccc}
\hline Species & Habit & Collection site & Sample code \\
\hline Cattleya brevipedunculata & Epiphyte & On Vellozia gigantea \\
Epidendrum saxatile & Epiphyte & On Vellozia piresiana \\
Epidendrum secundum & Saxicolous & Rock fracture \\
Grobya cipoensis & Epiphyte & On Vellozia gigantea \\
Pleurothallis teres & Rupicolous & On rocks & EP2, ES2, ES3 \& ES4 \\
\hline
\end{tabular}

Total DNA Extraction of endophytic fungi and ITS region amplification and sequencing

For molecular identification of the obtained endophytic fungi, total DNA was extracted from a portion of the mycelium grown in a Erlenmeyer flask containing Martin liquid medium (glucose $10 \mathrm{~g} \mathrm{~L}^{-1}$; peptone $5 \mathrm{~g}$ $\mathrm{L}^{-1} ; \mathrm{KH}_{2} \mathrm{PO}_{4} 1 \mathrm{~g} \mathrm{~L}^{-1} ; \mathrm{MgSO}_{4} 0.2 \mathrm{~g} \mathrm{~L}^{-1}$; rose bengal 0.06 $\mathrm{g} \mathrm{L}^{-1}$; and streptomycin $0.03 \mathrm{~g} \mathrm{~L}^{-1}$ ) or from a scraping of mycelium obtained in Petri dishes with PDA medium. The mycelium was transferred to $1.5 \mathrm{ml}$ microtubes and the DNA was extracted using the NucleoSpin ${ }^{\circledR}$ Soil extraction kit (Macherey Nagel), according to the manufacturer's instructions. The DNA extracts were suspended in $20 \mu \mathrm{L}$ of ultrapure water and quantified by electrophoresis in $0.8 \%$ agarose gel with ethidium bromide $0.7 \mathrm{mg} \mathrm{mL}^{-1}$.

The ITS region of nuclear rDNA was amplified from total DNA of the fungal endophytes. The primer pair ITS1/ITS4 (White et al. 1990) and the polymerase chain reaction conditions described by Gardes \& Bruns (1993) were used. The two strands of the amplified fragments were sequenced by Macrogen Inc. (Geumchun-gu, South Korea) using BigDye TM and a 3730xl Automatic Sequencer (Applied Biosystems).

\section{Sequence analysis}

Contigs were constructed from the two sequence strands of endophytic ITS using the Sequencher program version 4.5 (Gene Codes). Species richness was determined based on the number of Operational Taxonomic Units (OTUs), where each OTU represented sequences with at least $97 \%$ similarity. For this, the sequences were initially aligned by the ClustalW method (Katoh et al. 2005) using the MEGA program (Stecher et al. 2020). The alignment was then analyzed by the dist.seqs command to generate a matrix of calculated uncorrected pairwise distances, which was used to obtain the OTU list by the cluster command, both using the program Mothur (Schloss et al. 2009). Subsequently, the isolates were compared to sequences deposited in the NCBI database (GenBank, http://www.ncbi.nlm.nih.gov) and the UNITE Community database (https://mothur.org/ wiki/unite_its_database/). Comparisons with the NCBI sequences were performed using the BLASTn algorithm (Altschul et al. 1997) and using the sequence with the lowest e-value and the highest identity percentage as a reference. Comparisons with UNITE Community reference sequences were performed using the command classify. seqs of the Mothur program. These data were plotted using the program RStudio v1.1.463.

Sequences of Tulasnella and Serendipita were aligned separately with reference sequences available from the NCBI database and the UNITE Community database (Abarenkov et al. 2020). Tulasnella sequences were analyzed with other sequences of the same genus. Serendipita sequences were analyzed initially with sequences of the order Sebacinales and later with sequences of the family Serendipitaceae. The sets of sequences were aligned with the MAFFT v7.453 program using the L-INS-i strategy. The Hasegawa-KishinoYano DNA replacement model was obtained after analyzing the alignment of the sequences in the MrModeltest program (Nylander 2004), based on the Akaike information criterion. Phylogenetic reconstruction was performed by Bayesian inference using MrBayes 3.2.6 software (Ronquist et al. $2012)$ and the MCMC method (100,000,000 generations, 2 runs and 4 chains) at CIPRES Science Gateway (Miller et al. 2010). The results of the Bayesian analysis were evaluated in the program Tracer v1.7.1 (Rambaut et al. 2018) and the trees edited in FigTree v1.4.4. The SH DOI codes of each sequence used in the phylogenetic analyses are presented on the trees according to the identification provided by the UNITE platform. The access codes for NCBI or other platforms were also reported.

\section{RESULTS}

Sixty-three isolates of endophytic fungi were obtained, of which 32 were identified molecularly (Tab. 2). The other isolates did not maintain viability until DNA extraction or presented problems during amplification or sequencing phases, preventing the acquisition of sequence data for molecular identification. The 32 isolates were clustered among 25 OTUs (Fig. 1), suggesting a richness of 25 species of endophytic fungi associated with the studied orchids. The orchid $C$. brevipedunculata had the most isolates (10) and OTUs (7), while G. cipoensis had the fewest, with three isolates and three OTUs (Fig. 1). Epidendrum saxatile, E. secundum and $P$. teres had, respectively four, eight and seven isolates and four, seven and five OTUs. 


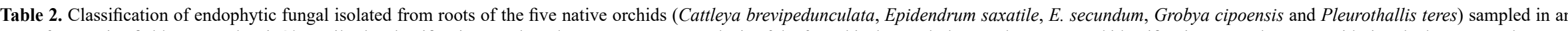

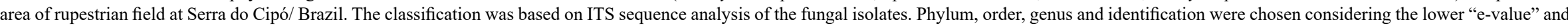
higher identity percentage (Id\%), to NCBI platform, and by "bootstrap" value (Bs), to UNITE platform

\begin{tabular}{|c|c|c|c|c|c|c|c|c|c|c|c|c|}
\hline \multirow{2}{*}{ Phylum } & \multirow{2}{*}{ Order } & \multirow{2}{*}{ OTU } & \multirow{2}{*}{ Isolates } & \multirow{2}{*}{ Access } & \multirow{2}{*}{ Identification } & \multicolumn{4}{|c|}{ NCBI } & \multicolumn{3}{|c|}{ UNITE } \\
\hline & & & & & & Access & Identification & E-value & Id\% & Level* & Identification & Bs \\
\hline \multirow[t]{23}{*}{ Ascomycota } & Boliniales & Otu10 & GC3A1 & KX185547 & Endoxyla sp. & NR_111790 & Endoxyla mallochii & $3.00 \mathrm{E}-127$ & 93.18 & $\mathrm{c}$ & Sordariomycetes & 98 \\
\hline & Botryosphaeriales & Otu22 & $\mathrm{SOC} 3 \mathrm{C} 2$ & KX185536 & Endomelanconiopsis sp. & NR_158434 & $\begin{array}{l}\text { Endomelanconiopsis } \\
\text { freycinetiae }\end{array}$ & 0 & 98.41 & $\mathrm{~s}$ & $\begin{array}{l}\text { Endomelanconiopsis } \\
\text { microspora }\end{array}$ & 96 \\
\hline & & Otu18 & $\mathrm{EP} 2 \mathrm{C} 5$ & KX185561 & Neofusicoccum sp. & NR_152945 & $\begin{array}{l}\text { Neofusicoccum } \\
\text { mangiferae }\end{array}$ & $1.00 \mathrm{E}-131$ & 94.97 & $\mathrm{f}$ & Botryosphaeriaceae & 94 \\
\hline & Capnodiales & Otu11 & $\mathrm{ES} 2 \mathrm{C} 1$ & KX185543 & Toxicocladosporium sp. & NR_111765 & $\begin{array}{l}\text { Toxicocladosporium } \\
\text { strelitziae }\end{array}$ & $1.00 \mathrm{E}-155$ & 97.49 & $\mathrm{~g}$ & $\begin{array}{l}\text { Toxicocladosporium } \\
\text { sp. }\end{array}$ & 100 \\
\hline & Coniochaetales & Otu07 & $\mathrm{SOC} 2 \mathrm{~A} 3$ & KX185532 & Coniochaeta sp. & NR_144912 & Coniochaeta decumbens & 0 & 99.77 & $\mathrm{f}$ & Coniochaetaceae & 85 \\
\hline & & Otu07 & $\mathrm{SOC} 2 \mathrm{C} 3$ & KX185537 & Coniochaeta sp. & NR_157478 & Coniochaeta cipronana & 0 & 98.37 & $\mathrm{f}$ & Coniochaetaceae & 97 \\
\hline & & Otu16 & РT3B5 & KX185556 & Coniochaeta fasciculata & NR_154770 & Coniochaeta fasciculata & 0 & 98.40 & $\mathrm{~s}$ & $\begin{array}{l}\text { Lecythophora } \\
\text { fasciculata }\end{array}$ & 95 \\
\hline & Eurotiales & Otu23 & SOC4C2 & KX185534 & Aspergillus sp. & NR_135361 & Aspergillus tabacinus & 0 & 100.00 & $\mathrm{~s}$ & $\begin{array}{l}\text { Aspergillus } \\
\text { subversicolor }\end{array}$ & 100 \\
\hline & & Otu01 & PT2B5 & KX185560 & Penicillium citrinum & NR_121224 & Penicillium citrinum & $2.00 \mathrm{E}-114$ & 100.00 & $\mathrm{~s}$ & Penicillium citrinum & 92 \\
\hline & & Otu01 & EE2B1 & KX185562 & Penicillium citrinum & NR_121224 & Penicillium citrinum & 0 & 100.00 & $\mathrm{~s}$ & Penicillium citrinum & 92 \\
\hline & & Otu06 & SOC $3 \mathrm{~A} 3$ & KX185535 & Talaromyces sp. & NR_120179 & Talaromyces amestolkiae & $4.00 \mathrm{E}-166$ & 100.00 & $\mathrm{~g}$ & Talaromyces sp. & 100 \\
\hline & & Otu06 & GC4D2 & KX185548 & Talaromyces stollii & NR_111781 & Talaromyces stollii & 0 & 99.75 & $\mathrm{~s}$ & Talaromyces stollii & 100 \\
\hline & Helotiales & Otu05 & $\mathrm{ES} 4 \mathrm{C} 5$ & KX185540 & Pezicula sp. & NR_155611 & Pezicula melanigena & 0 & 97.55 & $\mathrm{~g}$ & Cryptosporiopsis sp. & 100 \\
\hline & & Otu05 & $\mathrm{ES} 4 \mathrm{C} 3$ & KX185545 & Pezicula sp. & NR_155611 & Pezicula melanigena & $3.00 \mathrm{E}-177$ & 97.51 & $\mathrm{~g}$ & Cryptosporiopsis sp. & 100 \\
\hline & & Otu02 & PT2C2 & KX185557 & Pezicula sp. & NR_155611 & Pezicula melanigena & 0 & 97.39 & $\mathrm{f}$ & Dermateaceae & 100 \\
\hline & & Otu02 & PT2C5 & KX185558 & Pezicula sp. & NR_155611 & Pezicula melanigena & 0 & 97.18 & $\mathrm{f}$ & Dermateaceae & 100 \\
\hline & & Otu19 & $\mathrm{ES} 2 \mathrm{C} 2$ & KX185543 & Scytalidium sp. & NR_160179 & Scytalidium vaccinii & $1.00 \mathrm{E}-171$ & 93.38 & $\mathrm{c}$ & Leotiomycetes & 100 \\
\hline & Hypocreales & Otu09 & GC3B5 & KX185546 & Fusarium sp. & NR_130690 & Fusarium keratoplasticum & $5.00 \mathrm{E}-175$ & 99.70 & $\mathrm{~g}$ & Fusarium sp. & 84 \\
\hline & Trichosphaeriales & Otu08 & ES3B5 & KX185544 & Nigrospora sp. & NR_153480 & Nigrospora hainanensis & $6.00 \mathrm{E}-164$ & 97.34 & o & Trichosphaeriales & 100 \\
\hline & Xylariales & Otu13 & SOC3A4 & KX185531 & Xylaria sp. & NR_153200 & Xylaria bambusicola & 0 & 94.61 & $\mathrm{~g}$ & Xylaria sp. & 98 \\
\hline & & Otu12 & EE2A & KX185550 & Daldinia sp. & NR_147520 & Daldinia hausknechtii & 0 & 98.85 & $\mathrm{~s}$ & Daldinia loculata & 95 \\
\hline & & Otu24 & $\mathrm{SOC} 2 \mathrm{C} 4$ & KX185533 & Hypoxylon sp. & NR_145212 & Hypoxylon hinnuleum & $4.00 \mathrm{E}-141$ & 88.89 & $\mathrm{~g}$ & Hypoxylon sp. & 80 \\
\hline & & Otu14 & EE2B5 & KX185552 & Nodulisporium sp. & NR 166005 & Nodulisporium indicum & 0 & 93.13 & o & Xylariales & 100 \\
\hline
\end{tabular}


Table 2. Cont.

\begin{tabular}{|c|c|c|c|c|c|c|c|c|c|c|c|c|}
\hline \multirow{2}{*}{ Phylum } & \multirow{2}{*}{ Order } & \multirow{2}{*}{ OTU } & \multirow{2}{*}{ Isolates } & \multirow{2}{*}{ Access } & \multirow{2}{*}{ Identification } & \multicolumn{4}{|c|}{ NCBI } & \multicolumn{3}{|c|}{ UNITE } \\
\hline & & & & & & Access & Identification & E-value & Id\% & Level* & Identification & Bs \\
\hline \multirow[t]{9}{*}{ Basidiomycota } & Cantharellales & Otu21 & SOC2A5 & KX185539 & Tulasnella sp. & NR_160570 & $\begin{array}{l}\text { Tulasnella } \\
\text { cumulopuntioides }\end{array}$ & $1.00 \mathrm{E}-146$ & 87.97 & $\mathrm{f}$ & Tulasnellaceae & 92 \\
\hline & & Otu25 & EE2B3 & KX185551 & Tulasnella sp. & NR_160569 & Tulasnella dendritica & $3.00 \mathrm{E}-48$ & 86.63 & $\mathrm{p}$ & Basidiomycota & 100 \\
\hline & & Otu03 & PT2A5 & KX185555 & Tulasnella sp. & NR_160570 & $\begin{array}{l}\text { Tulasnella } \\
\text { cumulopuntioides }\end{array}$ & $2.00 \mathrm{E}-154$ & 88.41 & $\mathrm{~g}$ & Epulorhiza sp. & 100 \\
\hline & & Otu03 & РT3B3 & KX185553 & Tulasnella sp. & NR_160570 & $\begin{array}{l}\text { Tulasnella } \\
\text { cumulopuntioides }\end{array}$ & $2.00 \mathrm{E}-164$ & 88.20 & $\mathrm{~g}$ & Epulorhiza sp. & 100 \\
\hline & & Otu15 & РT3C2 & KX185554 & Tulasnella sp. & NR_160570 & $\begin{array}{l}\text { Tulasnella } \\
\text { cumulopuntioides }\end{array}$ & $4.00 \mathrm{E}-176$ & 90.55 & $\mathrm{~g}$ & Tulasnella sp. & 100 \\
\hline & & Otu17 & SOA3 & KX185559 & Tulasnella sp. & NR_160569 & Tulasnella dendritica & $9.00 \mathrm{E}-48$ & 86.55 & $\mathrm{~g}$ & Tulasnella sp. & 86 \\
\hline & Sebacinales & Otu04 & SOC2B3 & KX185538 & Serendipita sp. & NR_144842 & Serendipita herbamans & $2.00 \mathrm{E}-93$ & 88.50 & o & Serendipitaceae & 93 \\
\hline & & Otu04 & ES3A1 & KX185541 & Serendipita sp. & NR_144842 & Serendipita herbamans & $1.00 \mathrm{E}-105$ & 85.95 & o & Serendipitaceae & 82 \\
\hline & & Otu20 & $\mathrm{ES} 2 \mathrm{~A} 4$ & KX185542 & Serendipita sp. & NR_144842 & Serendipita herbamans & $7.00 \mathrm{E}-104$ & 86.42 & o & Serendipitaceae & 98 \\
\hline
\end{tabular}

* p: phylum; o: order; c: class; f: family; g: genera; s: species. 


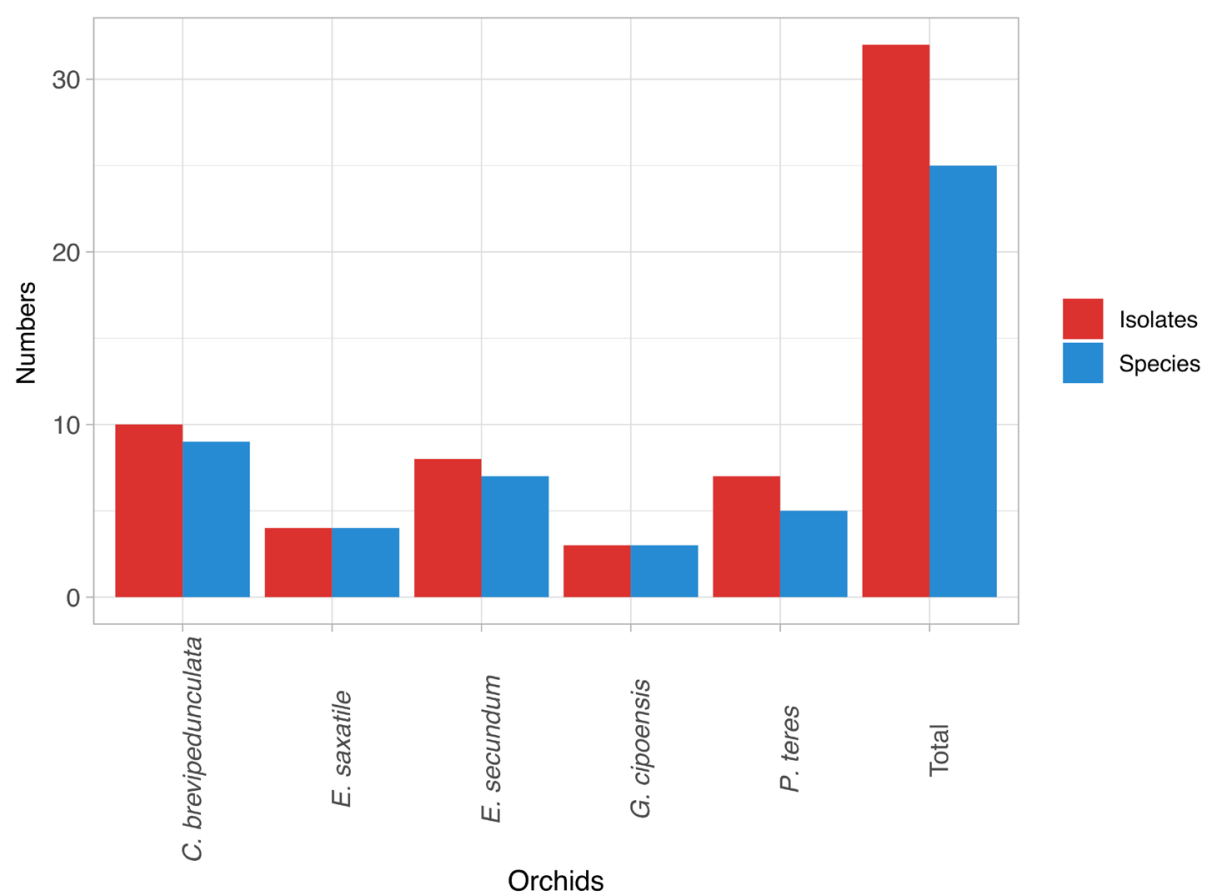

Figure 1. Number of isolates and species of endophytic fungi obtained from roots of the five native orchids (Cattleya brevipedunculata, Epidendrum saxatile, E. secundum, Grobya cipoensis and Pleurothallis teres) sampled in a rupestrian grasslands of Serra do Cipó, Brazil. Species definition was based on ITS sequence analysis, considering isolates with greater than $97 \%$ similarity as belonging to the same fungal species.

Comparisons of the endophytic ITS sequences to those from NCBI and UNITE failed to identify all of the isolates at species level. However, the association between the results obtained from classifications using the different databases allowed identifying the endophytes to the genus level (Tab. 2).

Twenty-three isolates were classified as belonging to the phylum Ascomycota and nine to the phylum Basidiomycota (Tab. 2, Fig. 2). Among the isolates of Ascomycota were 16 different genera and nine orders: Boliniales, Botryosphaeriales, Capnodiales, Coniochaetales, Eurotiales, Helotiales, Hypocreales, Trichosphaeriales and Xylariales (Tab. 2, Fig. 2 and 3). The isolates of Basidiomycota belonged to two genera, Tulasnella and Serendipita, of two different orders, Cantharellales and Sebacinales, respectively (Tab. 2, Figs. 2, 3).

Phylogenetic analysis considering 198 Sebacinales reference sequences confirmed that isolates SOC2B3, ES3A1 and ES2A4 belonged to the genus Seperendita of the family Serendipitaceae (data not shown). A phylogenetic reconstruction was performed with 34 sequences from this family (Fig. 4), disregarding the sequences of Serendipita indica (Sav. Verma, Aj. Varma, Rexer, G. Kost \& P. Franken) M. Weiß et al. and S. williamsii (A. Zuccaro \& M. Weiß) M. Weiß et al., which differed greatly from the studied endophytic sequences. Two sequences of Paulisebacina allantoidea (R. Kirschner \& Oberw.) Oberw., family Sebacinaceae, were used as an outgroup. The isolates SOC2B3, ES3A1 and ES2A4 did not group with sequences of any of the previously identified species, and only with sequences of fungi classified as Serendipitaceae; however, they presented proximity to the clade of
Serendipita vermifera (Oberw.) P. Roberts. The ES2A4 isolate grouped with a mycorrhizal fungus of the Brazilian orchid Hoffmannseggella caulescens (Lindl.) HGJones (SH197470.07FU). The isolates SOC2B3 and ES3A1 grouped with mycorrhizal fungi of Hoffmannseggella cinnabarina (Batem. Ex Lindl.; SH197471.07FU, SH197472.07FU and SH197474.07FU), also from Brazil, and of orchids from Reunion Island (SH197483.07FU and SH105390.07FU) (Fig. 4B).

Phylogenetic analysis containing 282 Tulasnellaceae reference sequences confirmed the classification of isolates EE2B3, PT3C2, PT3B3, PT2A5, SOA3 and SOC2A5 as Tulasnella sp. (data not included). A phylogenetic reconstruction was performed with 70 Tulasnella sequences, considering the species Tulasnella eichleriana Bres., $T$. tomaculum P. Roberts and T. violea (Quél.) Bourdot \& Galzin as outgroups (Fig. 5). Isolate EE2B3 formed a clade with three isolates of Tulasnella: two mycorrhizal orchids from Ecuador (SH193016.07FU and SH193015.07FU) and one from Costa Rica (SH193018.07FU). Isolate SOA3 grouped with symbionts of orchids from Japan (SH203337.07FU and SH203339.07FU) and Reunion Island (SH203338.07FU). Isolate SOC2A5 showed high similarity with two mycorrhizal Tulasnella from Ecuador (SH195570.07FU and SH192337.07FU), one from Reunion Island (SH195571.07FU) and another from Costa Rica (SH195573.07FU). Isolate PT3C2 grouped with isolates from Ecuador (SH199030.07FU and SH213190.07FU) and South Africa (SH213195.07FU). Finally, isolates PT3B3 and PT2A5 grouped with a Tulasnella from the United States (SH212756.07FU), in a clade close to T. caulospora (Boud.) Juel (SH212756.07FU). 


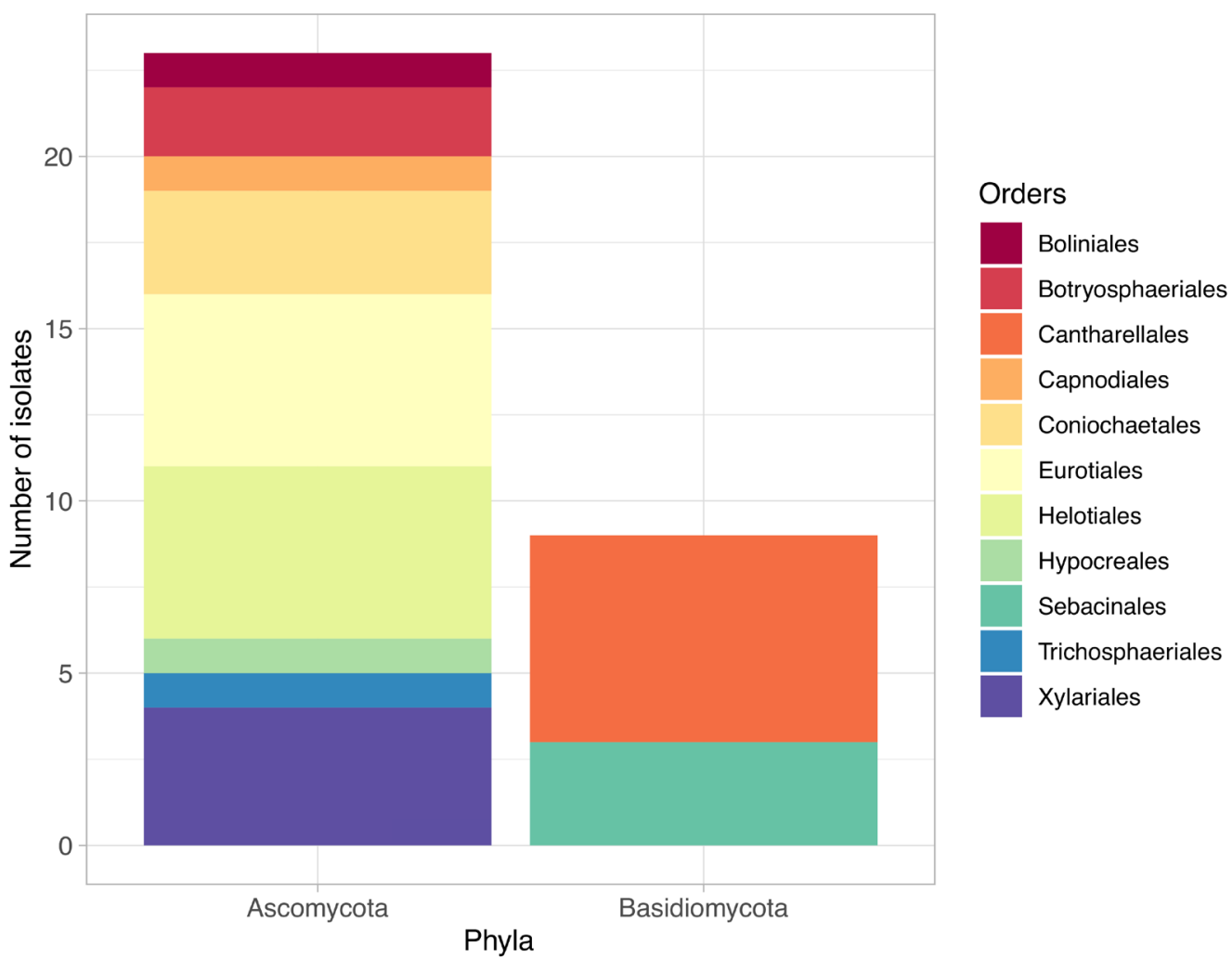

Figure 2. Number of fungal isolates at the levels of phylum and order obtained from roots of the five native orchids (Cattleya brevipedunculata, Epidendrum saxatile, E. secundum, Grobya cipoensis and Pleurothallis teres) sampled in an area of rupestrian grasslands at Serra do Cipó/ Brazil.

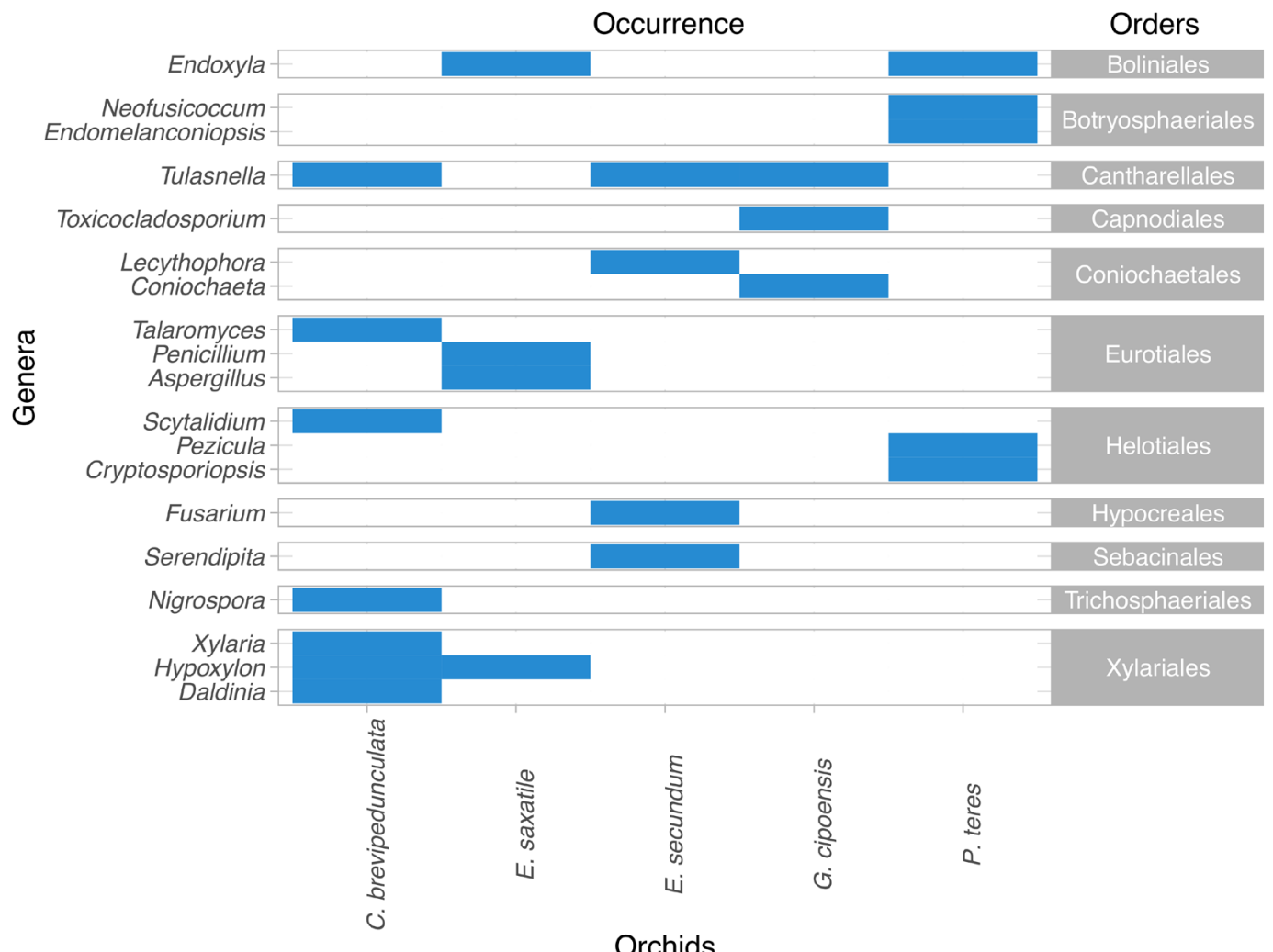

Figure 3. Fungal genera occurring as endophytic in roots of the five native orchids (Cattleya brevipedunculata, Epidendrum saxatile, E. secundum, Grobya cipoensis and Pleurothallis teres) sampled in a rupestrian grasslands of Serra do Cipó, Brazil. 


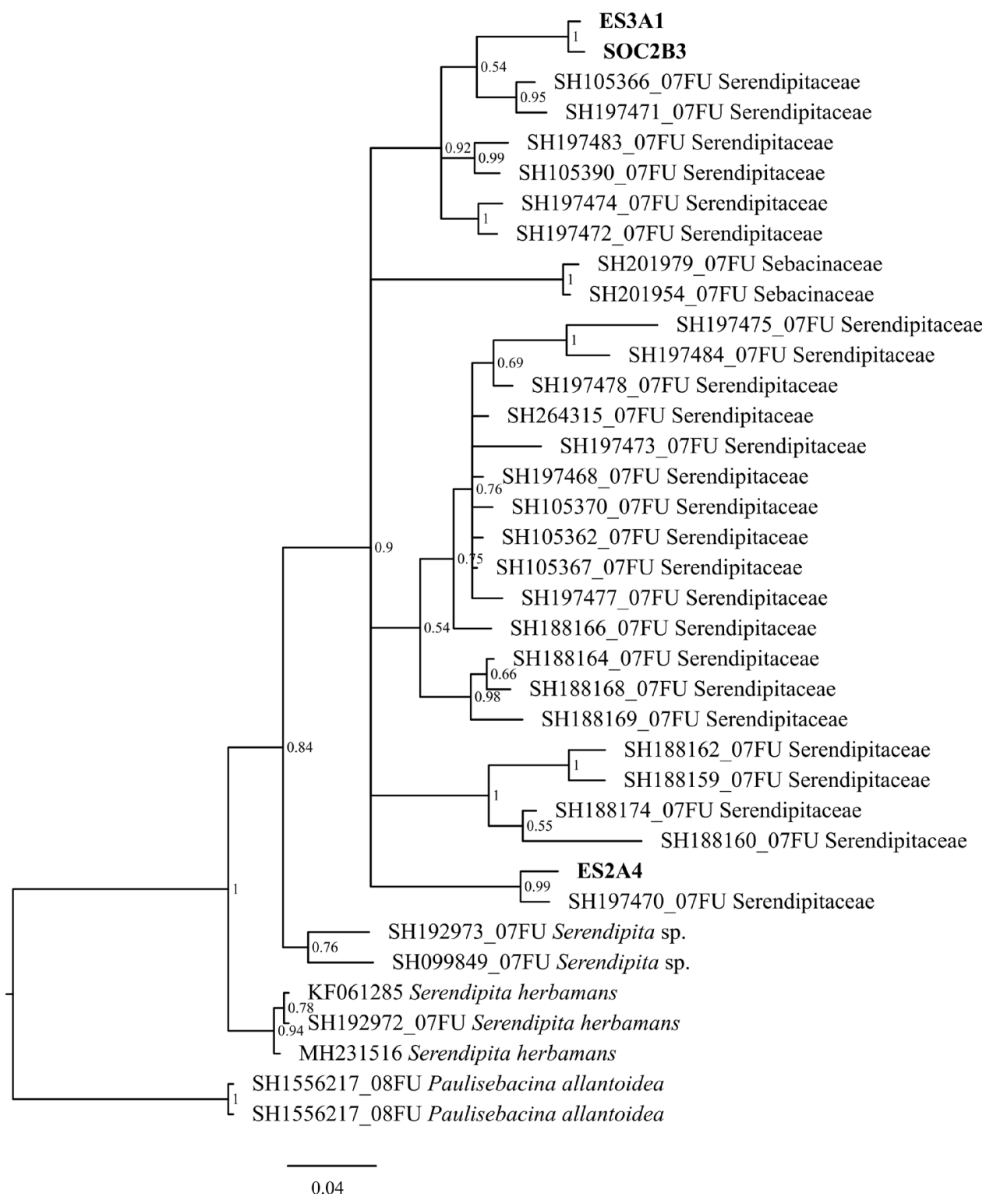

Figure 4. Phylogenetic inference of the endophytic fungal genus Serendipita generated by Bayesian analysis of ITS sequences. A posteriori probabilities are indicated on the nodes. Bold codes and respective NCBI access numbers for the isolates obtained from roots of the five native orchids (Cattleya brevipedunculata, Epidendrum saxatile, E. secundum, Grobya cipoensis and Pleurothallis teres) sampled in a rupestrian grasslands of Serra do Cipó, Brazil. Identification and accession number for NCBI and UNITE platform are provided to reference sequences.

\section{DISCUSSION}

Twenty-five OTUs were identified by the ITS sequence analysis of the 32 isolates, suggesting that 25 different fungal species establish associations with the roots of the studied orchids (Fig. 1). More than $70 \%$ of the OTUs were unique and only seven were represented by more than one isolate (Table 2). These values can be considered high when compared to the number of possible species obtained by other studies of cultivable endophytes (Pereira et al. 2005, 2014, Valadares et al. 2012, 2015). The present work, however, sampled different species of orchids growing on different substrates, while the other works investigated fewer orchids and less diverse habits. Since 25 species of fungi were determined from the 32 identified isolates, a greater effort at isolation would be expected to reveal even higher richness of endophytic fungi in association with the studied orchids.

Some of the studied orchids had associations with the same OTU, even when growing on different substrates. This was observed for the epiphytic orchid E. saxatile, which interacted with a fungus also isolated from the rupicolous species $P$. teres (Otu01); and for the epiphytic orchid C. brevipedunculata and the saxicolous $E$. secundum, which interacted with Otu04 isolates (Table 2). Cattleya brevipedunculata and G. cipoensis, growing as epiphytes, interacted with Otu06 isolates (Table 2). Adult plants of some orchids establish mycorrhizal associations to more easily obtain nutrients from the substrate (Dearlaney et al. 2017). Some plant species, however, may not establish 


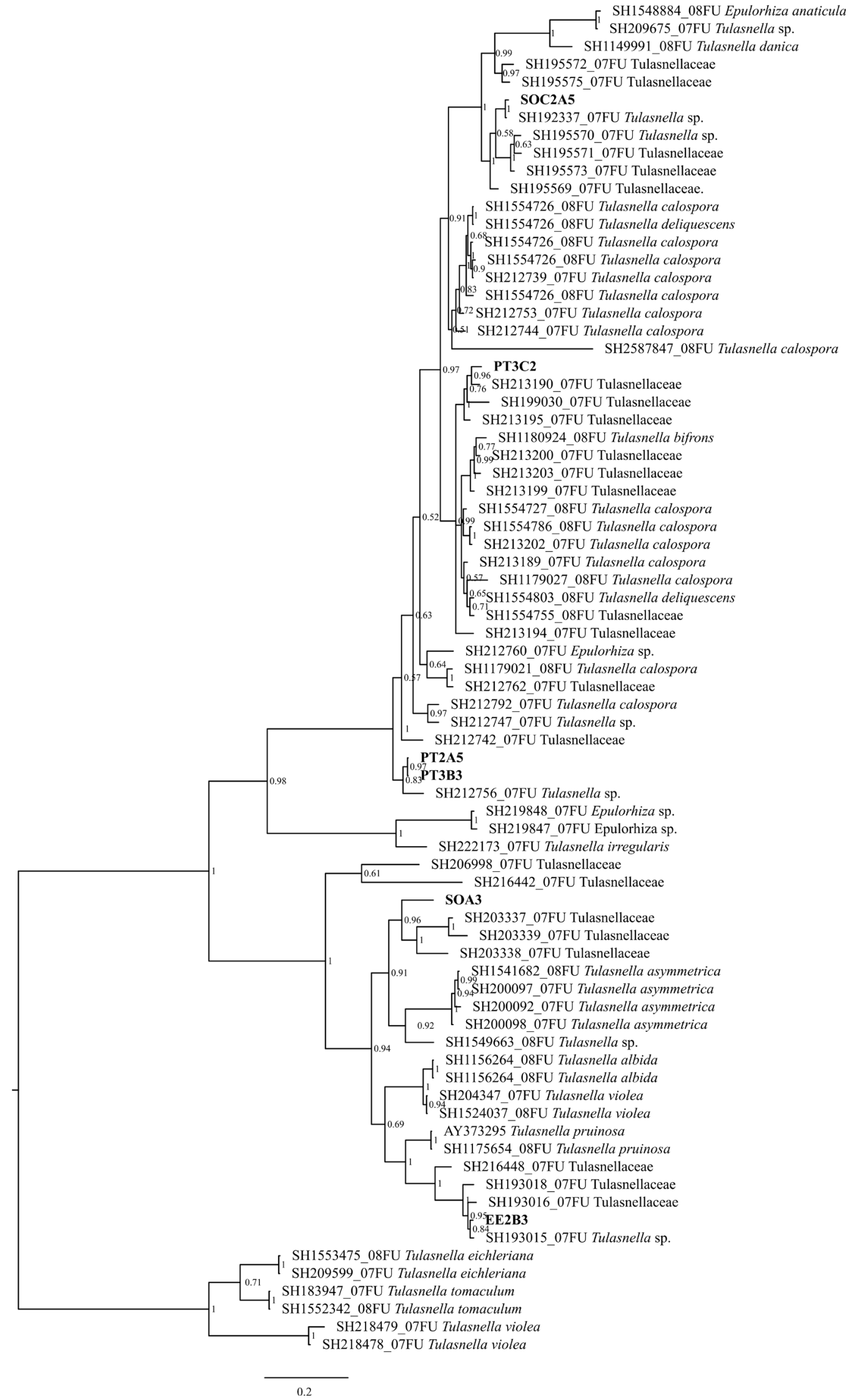

Figure 5. Phylogenetic inference of the endophytic fungal genus Tulasnella generated by Bayesian analysis of ITS sequences. A posteriori probabilities are indicated on the nodes. Bold codes and respective NCBI access numbers for isolates obtained from roots of the five native orchids (Cattleya brevipedunculata, Epidendrum saxatile, E. secundum, Grobya cipoensis and Pleurothallis teres) sampled in a rupestrian grasslands of Serra do Cipó, Brazil. Identification and accession number for NCBI and UNITE platform are provided to reference sequences. 
associations with the same mycorrhizal fungus when cooccurring in the same region and/or on the same substrate, to avoid competition (Valadares et al. 2015). But our data corroborate the observation that different species of orchids interact with the same mycorrhizal fungal isolates when they co-occur in the same area and/or substrate (Chen et al. 2019, Herrera et al. 2019).

The number of isolates for Ascomycota was more than 2.5 times that for Basidiomycota (Fig. 2, Table 2). Only the genera Serendipita and Tulasnella were observed among Basidiomycota isolates, and both genera are reported as mycorrhizal on several orchids (Dearnaley et al. 2017). In addition, in contrast with several studies on tropical orchids, the genus Ceratobasidium was not detected in the present work (Mosquera-Espinosa et al. 2013, Valadares et al. 2015).

During the isolation protocol employed here, only root fragments containing pelotons were transferred to isolation media. Since pelotons are considered a characteristic structure of mycorrhizal association in orchids, this protocol would favor the isolation of the mycorrhizal fungi (Pereira et al. 2014, Valadares et al. 2012, 2015). However, nonmycorrhizal endophytic fungi grow in roots without forming easily visible structures (Bayman \& Otero 2006) and can co-occur with the mycorrhizal fungi in root fragments (Azevedo 1998). If a non-mycorrhizal fungus is colonizing the root and presents a faster growth rate, it will be recultivated to the detriment of mycorrhizal fungi, making it possible to isolate non-mycorrhizal endophytes even by transferring fragments of the cortex containing pelotons.

Mycorrhizal and non-mycorrhizal endophytic fungi are extremely important to orchid maintenance in the field (Bayman \& Otero 2006, Salazar-Cerezo et al. 2018). Non-mycorrhizal fungi of Ascomycota and Basidiomycota have been described in other works (Waud et al. 2016, Salazar-Cerezo et al. 2018, Shah et al. 2019). Studies using independent cultivation methods molecularly identified a great diversity of fungal endophytes, revealing that the diversity of symbionts associated with orchid roots is much more complex than previously thought (Dearnaley et al. 2017, Waud et al. 2016, Shah et al. 2019). Faced with a large amount of information on the endophytic community of plants, the challenge is to understand the role of the fungal diversity of this microbial community interacting with a plant. Methods for proposing functional roles based on fungal classification have been developed (http://www.stbates.org/guilds/app.php), and permit a partial understanding of the role of each fungus detected in a sample of an environment (Cevallos et al. 2018).

Non-mycorrhizal and mycorrhizal fungi are assigned the roles of enhancing plant access to nutrients; protecting against desiccation; providing protection against pathogens by releasing secondary metabolites and by inducing plant resistance; and producing phytohormones that assist in plant development (Dutta et al. 2014, Ma et al. 2015). Moreover, mycorrhizal fungi are also responsible for the germination of orchid seeds under natural conditions (Peterson et al.
2004, Dearnaley et al. 2017, Yeh et al. 2019). Thus, nonmycorrhizal fungi are a fundamental component of the microbial community of the substrate.

Some Basidiomycota of the classes Atractiellomycetes and Agaricomycetes, as well as Ascomycota of the class Pezizomycetes, were listed as possibly being mycorrhizal (Dearnaley et al. 2012, 2017, Waud et al. 2016). However, among the isolates obtained in this study, only the Basidiomycota isolates of the genera Sebacina and Tulasnella, both from the class Agaricomycetes, can be considered mycorrhizal. Since the isolates of Ascomycota obtained in this study were not listed as mycorrhizal with orchids, they were considered as non-mycorrhizal endophytes.

Ascomycota corresponded to more than $70 \%$ of the isolates and OTUs in this study, and were obtained from all the orchids studied (Table 2), which is in accordance with their reported abundances in the endophytic communities of other orchids (Waud et al. 2016, Shah et al. 2019). This indicates the importance of Ascomycota as orchid endophytes that promote the growth of their hosts (Azevedo 1998, Selosse et al. 2004, Bayman \& Otero 2006, SalazarCerezo et al. 2018).

Some roles of the obtained Ascomycota groups are known. Species of the orders Botryosphaeriales and Capnodiales are found as pathogens, endophytes and saprobes degrading cellulose and other complex carbohydrates (Schoch et al. 2006). Eurotiales, represented here by the genera Aspergillus and Penicillium, comprises a group of morphologically and ecologically divergent fungi that are capable of growing in extreme environments and producing several secondary metabolites, such as penicillin (Geiser et al. 2006). Endophytic Penicillium isolates of orchids have shown the ability to produce gibberellins, thus suggesting potential for regulating plant growth (Salazar-Cerezo et al. 2018). The order Helotiales, one of the largest in the phylum Ascomycota (Wang et al. 2006a, 2006b), has been reported as being among the taxa with the greatest occurrence in other orchid species (Ma et al. 2015, Jaquemyn et al. 2016). These fungi have varied ecological and nutritional characteristics, and develop well in various ecosystems as pathogens, endophytes, mycorrhizae, ectomycorrhizae, parasites, terrestrial saprobes, and aquatic saprobes (Wang et al. 2006b). The present study obtained five isolates of this order, but only from $E$. secundum and $P$. teres, two orchid species observed to be preferentially saxicolous and rupicolous (Table 2).

The present study obtained a high number of representatives of the class Sordariomycetes, which includes the orders Xylariales, Trichosphaeriales, Hypocreales, Coniochaetales and Coniochaetales (Table 2). According to Zhang et al. (2006), this class includes endophytic organisms of plants, including mycoparasites and saprobes, the latter being involved in the decomposition and cycling of nutrients. Their hosts also benefit from increased resistance to infection by pathogens and insect predation through the production of bioactive compounds (Ma et al. 2015). 
Microorganisms of the genera Fusarium and Xylaria are known to be plant pathogens, but they may have potential for use in the germination of orchid seeds (Salifah et al. 2011). The genera Coniochaeta and Fusarium also were reported as endophytic of terrestrial orchids (Lee \& Eom 2017, Lee et al. 2017).

According to Hibbett et al. (2007), fungi of the class Agaricomycetes are common in all terrestrial environments and can be pathogens, parasites and symbionts of plants and animals, and many form fruiting bodies known as mushrooms. This class was represented here by Serendipita and Tulasnella, which belong to the orders Cantharellales and Sebacinales, respectively (Table. 2). Many fungi of these orders are referred to as rhizoctonioids (Roberts 1999, García et al. 2006). They are the most important mycorrhizal fungi of orchids (Dearnaley et al. 2017), and have been frequently reported as mycorrhizal with them (Robert 1999, García et al., 2006, Dearnaley et al., 2017).

Even with the large number of described species of Sebacinales and Tulasnella, and the availability of their sequences from NCBI and UNITE, it was not possible to identify the Serendipita and Tulasnella isolates of this work to species level due to the low similarity they exhibited with sequences in these databases (Fig. 4 and 5). The clades in which they were found contain only sequences of fungi without identification, and so they may represent undescribed species.

The Serendipita isolates of the present study grouped with endophytes from other orchids and were closest to endophytes from two orchids also from rupestrian grasslands in Minas Gerais, Brazil (Fig. 4). However, interpreting this as speciation due to geographical location is questionable, since a Serendipita observed in orchids from Reunion Island is in the same clade. The clade containing the Serendipita fungi of the present study was near the clade containing $S$. vermifera, a fungus often described as mycorrhizal of orchids and plants of other families (Weiss et al. 2004, Weiß et al. 2016). Serendipita vermifera represents a fungal complex, assembling isolates from different regions of the world that present similar morphological features, but high ITS variation (Weiß et al. 2016). These taxonomical complexes emerge from difficulties related to the association of morphological and molecular data in classification, and highlights the need to search for additional useful morphological and/or molecular characters that can enlighten fungal classification.

The same limitation has been reported for Tulasnella concerning the species T. calospora. Although mycorrhizal fungi isolated with various orchids have been reported as belonging to this species, phylogenetic analyses have suggested that this taxon encompasses different fungal species (Suarez et al. 2006). Four of the Tulasnella isolates of the present study (PT2A5, PT3B3, PT3C2 and SOC2A5) were placed in clades close to those containing T. calospora (Fig. 5), but the distances observed between the studied isolates and T. calospora, on phylogenetic tree and in comparisons with NCBI and UNITE sequences, revealed insufficient similarity to confirm this identification. Likewise, the Tulasnella isolates EE2B3 and SOA3 were not sufficiently similar to any sequence of any previously identified fungal species. These six isolates were similar to Tulasnella fungi observed in association with orchids in different parts of the world, indicating that they are cosmopolitan species.

Works with Brazilian orchids have demonstrated that the isolates from Cantharellales and Sebacinales, especially the genera Tulasnella and Ceratobasidium, is essential for the germination of orchid seeds, the early development of embryos and the growth of seedling development (Pereira et al. 2011, 2015, Guimarães et al. 2013, Valadares et al. 2012), and are frequently observed in association with adult plants (Pereira et al. 2005, Valadares et al. 2015). Therefore, Sebacina and Tulasnella isolates, the only mycorrhizal fungi isolates found, may be the main fungi responsible for orchid seed germination in the studied rupestrian grasslands. The structure of an endophytic fungal community, and its variation throughout the life cycle stages of a plant, are critical factors for maintaining orchids in natural conditions and deserving of further attention (Rasmussen $e t$ al. 2015, Shao et al. 2017). The high number of Ascomycota isolates suggests they are important components of the endophytic community of orchid roots in the studied rupestrian grasslands. Additionally, further studies are needed that describe species of fungal endophytes and study their roles in the life cycle of orchids.

\section{ACKNOWLEDGEMENT}

We thank the the Minas Gerais State Research Support Foundation (FAPEMIG) and National Council for Scientific and Technological Development $(\mathrm{CNPq})$ for maintaining the scientific initiation scholarships and for financing the projects (CAG-APQ-01744-13 and APQ-429102/2016-0, respectively).

\section{REFERENCES}

Abarenkov, K., Zirk, A., Piirmann, T., Pöhönen, R., Ivanov, F., Nilsson, R.H., Kõljalg, U. 2020. Full UNITE+INSD dataset for Fungi. UNITE Community. 10.15156/BIO/786372.

Abreu, M.E.P., Garcia, Q.S. 2005. Efeito da luz e da temperatura na germinação de quatro espécies de Xyris 1. (Xyridaceae) ocorrentes na Serra do Cipó, MG, Brasil. Acta Botanica Brasilica 19:149-154.

Altschul, S.F., Madden T.L., Schaffer A.A. et al. 1997. Gapped BLAST and PSI-BLAST: a new generation of protein database search programs. Nucleic Acids Research 25:3389-3402.

Antoniolli ZI, Kaminski J. 1991. Micorrizas. Ciência Rural. V1, n3, P 441-455

Azevedo, J.L. 1998. Micro-organismos endofíticos. In: Melo IS, Azevedo JL (Eds.) Ecologia Microbiana. Jaguariuna: Embrapa - CNPMA. 4:117-137

Bayman, P.J., Otero, T. 2006. Microbial Endophytes of Orchid Roots. In: Schulz B, Boyle C, Sieber T (Ed.) Microbial Root Endophytes. Berlin: Springer-Verlag.

Boldrini, R.F., Santos, W.O., Cruz, Z.M.A., Ramos, A.C. 2010. Bases da associação micorrízica orquidóide. Natureza online 8:140-145. 
Cardoso, J.C., Israel, M. 2005. Levantamento de espécies da família Orchidaceae em Águas de Sta. Bárbara - SP e seu cultivo. Horticultura Brasileira 23:169-173.

Cevallos, S., Herrera, P., Sanchez-Rodríguez, A., Declerck, S., Suarez, J.P. 2018. Untangling factors that drive community composition of root associated fungal endophytes of Neotropical epiphytic orchids. Fungal Ecology $34: 67-75$.

Chen, Y., Gao, Y., Song, L., Zhao, Z., Guo, S., Xing, X. 2019. Mycorrhizal fungal community composition in seven orchid species inhabiting Song Mountain, Beijing, China. Science China Life Sciences 62(6):838-847.

Dearnaley, J.D.W., Martos, F., Selosse, M.A. 2012. Orchid mycorrhizas: molecular ecology, physiology, evolution and conservation aspects. In: Hock, B. (Ed). The Mycota. IX: Fungal associations, 2nd ed. Berlin: Springer-Verlag.

Dearnaley, J., Perotto, S., Selosse, M.A. 2017. Structure and development of orchid mycorrhizas. In: Martin, F. (Ed.) Molecular mycorrhizal symbiosis, John Wiley \& Sons, Inc.

Dutta, D., Puzari, K.C., Gogoi, R., Dutta, P. 2014. Endophytes: Exploitation as a Tool in Plant Protection. Brazilian Archives of Biology and Technology 57: 21-629.

Fay, M.F. 2018. Orchid conservation: how can we meet the challenges in the twenty-first century? Botanical Studies 59:16.

García, V.G., Onco, M.A.P., Susan, V.R. 2006. Review. Biology and Systematics of the form genus Rhizoctonia. Spanish Journal of Agricultural Research 4:55-79

Gardes, M., Bruns, T.D. 1993. ITS primers with enhanced specificity for basidiomycetes: application to the identification of mycorrhizae and rust. Molecular Ecology 2:113-118.

Geiser, D.M., Gueidan, C., Miadlikowska, J. et al. 2006. Eurotiomycetes: Eurotiomycetidae and Chaetothyriomycetidae. Mycologia 98:10531064.

Guimarães, F.A.R., Pereira, M.C., Felício, C.S., Torres, D.P., Oliveira, S.F., Veloso, T.G.R., Kasuya, M.C.M. 2013. Symbiotic propagation of seedlings of Cyrtopodium glutiniferum Raddi (Orchidaceae). Acta Botanica Brasilica 27:590-596.

Herrera, P., Suarez, J.P., Sanchez-Rodríguez, A., Molina, M.C., Prieto, M., Mendez, M. 2019. Many broadly-shared mycobionts characterize mycorrhizal interactions of two coexisting epiphytic orchids in a high elevation tropical forest. Fungal Ecology 39:26e36.

Hibbett, D.S., Binder, M., Bischoff, J.F. 2007. A higher-level phylogenetic classification of the Fungi. Mycological Research 111:509-547

Jacquemyn, H., Waud, M., Lievens, B., Brys, R. 2016. Differences in mycorrhizal communities between Epipactis palustris, E. helleborine and its presumed sister species E. neerlandica. Annals of Botany 118: $105-114$.

Jones, D.L. 2006. A complete guide to native orchids of Australia including the Island Territories. Sydney: Reed New Hol.

Katoh, K., Kuma, K.I., Toh, H., Miyata, T. 2005. MAFFT version 5: Improvement in accuracy of multiple sequence alignment. Nucleic Acids Research 33:511-518.

Kuga, Y., Sakamoto, N., Yurimoto, H. 2014. Stable isotope cellular imaging reveals that both live and degenerating fungal pelotons transfer carbon and nitrogen to orchid protocorms. New Phytologist 202:594-605.

Lee, B.H., Eom, A.H. 2017. Five Species of Endophytic Fungi Isolated from Roots of Native Orchid Plants from Korea. The Korean Journal of Mycology 45:355-361.

Lee, B.H., Kwon, W.J., Kim, J.Y., et al. 2017. Differences among endophytic fungal communities Isolated from the roots of Cephalanthera longibracteata collected from different sites in Korea. Mycobiology 45:312-317.

Ma, X., Kang, J., Nontachaiyapoom, S., Wen, T., Hyde, K.D. 2015. Non-mycorrhizal endophytic fungi from orchids. Current Science 109:72-87.

McCormick, M.K., Taylor, D.L., Whigham, D.F., Burnett, R.K. 2016. Germination patterns in three terrestrial orchids relate to abundance of mycorrhizal fungi. Journal of Ecolology 104:744-754.

Miller, M.A., Pfeiffer, W., and Schwartz, T. 2010. Creating the CIPRES Science Gateway for inference of large phylogenetic trees. Proceedings of the Gateway Computing Environments Workshop (GCE), 14 Nov. 2010, New Orleans, LA pp 1 - 8.
Mosquera-Espinosa, A.T., Bayman, P., Prado, G.A. et al. 2013. The double life of Ceratobasidium : orchid mycorrhizal fungi and their potential for biocontrol of Rhizoctonia solani sheath blight of rice. Mycologia. 105:141-150.

Nylander, J.A.A. 2004. MrModeltest v2 Program distributed by the author. Uppsala University, Sweden, Evolutionary Biology Centre.

Pereira, O.L., Kasuya, M.C.M., Rollemberg, C.L., Borges, G.M. 2005. Isolamento e identificação de fungos micorrízicos rizoctonióides associados a três espécies de orquídeas epífitas neotropicais no Brasil. Revista Brasileira de Ciência do Solo 29:191-197.

Pereira, M.C., Torres, D.P., Guimarães, F.A.R., Pereira, O.L., Kasuya, M.C.M. 2011. Germinação de sementes e desenvolvimento de protocormos de Epidendrum secundum Jacq. (Orchidaceae) em associação com fungos micorrízicos do gênero Epulorhiza. Acta Botanica Brasilica 25:534-541.

Pereira, M.C., Coelho, I.S., Valadares, R.B.S., Oliveira, S.F., Bocayuva, M., Pereira, O.L., Araújo, E.F., Kasuya, M.C.M. 2014. Morphological and molecular characterization of Tulasnella spp. fungi isolated from the roots of Epidendrum secundum, a widespread Brazilian orchid. Symbiosis 62:111-121.

Pereira, M.C., Rocha, D.I., Veloso, T.G.R., Pereira, O.L., Francino, D.M.T., Meira, R.M.S.A., Kasuya, M.C.M. 2015. Characterization of seed germination and protocorm development of Cyrtopodium glutiniferum (Orchidaceae) promoted by mycorrhizal fungi Epulorhiza spp. Acta Botanica Brasilica 29:567-574.

Peterson, R.L., Massicotte, H.B., Melville, L.H. 2004. Mycorrhizas: Anatomy and Cell Biology. NRC Research Press, Ottawa.

Rambaut, A., Drummond, A.J., Xie, D., Baele, G., Suchard, M.A. 2018. Posterior summarisation in Bayesian phylogenetics using Tracer 1.7. Systematic Biology. syy032. doi:10.1093/sysbio/syy032

Rasmussen, H.N., Dixon, K.W., Jersáková, J., Tesitelová, T. 2015. Germination and seedling establishment in orchids: a complex of requirements. Annals of Botany 116:391-402.

Roberts, P. 1999. Rhizoctonia-forming Fungi: a taxonomic guide. Royal Botanical Gardens, Kew Publishing.

Ronquist, F., M. Teslenko, P. van der Mark, D.L. Ayres, A. Darling, S. Höhna, B. Larget, L. Liu, M.A. Suchard, and J.P. Huelsenbeck. 2012. MRBAYES 3.2: Efficient Bayesian phylogenetic inference and model selection across a large model space. Systematic Biology 61:539-542.

Salazar-Cerezo, S., Martinez-Montiel, N., Cruz-Lopez, M.C., MartinezContreras, R.D. 2018. Fungal diversity and community composition of culturable fungi in Stanhopea trigrina cast gibberellin producers. Frontiers in Microbiology 9: 612.

Salifah, H.A.B., Muskhazli, M., Rusea, G., Nithiyaa, P. 2011. Variation in mycorrhizal specificity for in vitro symbiotic seed germination of Grammatophyllum speciosum Blume. Sains Malaysiana 40:451-455.

Shao, S.C., Burgess, K.S., Cruse-Sanders, J.M. et al. 2017. Using in situ symbiotic seed germination to restore over-collected medicinal orchids in Southwest China. Frontiers in Plant Science 8: 888.

Schloss, P.D., Westcott, S.L., Ryabin, T., Hall, J.R., Hartmann, M., Hollister, E.B., Lesniewski, R.A., Oakley, B.B., Parks, D.H., Robinson, C.J. and Sahl, J.W. 2009. Introducing mothur: Opensource, platform-independent, community-supported software for describing and comparing microbial communities. Applied and Environmental Microbiology 75(23):7537-41.

Schoch, C.L., Shoemaker, R.A., Seifert, K.A. et al. 2006. A multigene phylogeny of the Dothideomycetes using four nuclear loci. Mycologia 98:1041-1052.

Selosse, M.A., Faccio, A., Scappaticci, G., Bonfante, P. 2004. Chlorophyllous and Achlorophyllous Specimens of Epipactis microphylla (Neottieae, Orchidaceae) Are Associated with Ectomycorrhizal Septomycetes, including Truffles. Microbial Ecology 47:416-426.

Selosse, M.A., Richard, F., He, X., Simard, S.W. 2006. Mycorrhizal networks: des liaisons dangereuses? TRENDS in Ecology and Evolution 21:621-628.

Shah, S., Shrestha, R., Maharjan, S., Selosse, M., Pant, B. 2019. Isolation and Characterization of Plant Growth-Promoting Endophytic Fungi from the Roots of Dendrobium moniliforme. Plants 8:5.

Smith, S.E., Read, D.J. 2008. Mycorrhizal symbiosis. 3 ed. San Diego: Academic Press. 
Stecher, G., Tamura, K. and Kumar, S. 2020. Molecular evolutionary genetics analysis (MEGA) for macOS. Molecular Biology and Evolution, 37(4), pp.1237-1239.

Suarez, J.P., Weiß, M., Abele, A., Garnica, S., Oberwinkler, F., Kottke, I. 2006. Diverse tulasnelloid fungi form mycorrhizas with epiphytic orchids in an Andean cloud forest. Mycological Research 110: 1257-1270.

The Plant List. 2020. The plant list, ver. 1. http://www.theplantlist.org. Accessed 10 Fev. 2020.

Valadares, R.B.S., Pereira, M.C., Otero, J.T., Cardoso, E.J. 2012. Narrow fungal mycorrhizal diversity in a population of the orchid Coppensia doniana. Biotropica 44:114-122.

Valadares, R.B.S., Otero, J.T., Pereira, M.C., Cardoso, E.J.B.N. 2015. The epiphytic orchids Ionopsis utricularioides and Psygmorchis pusilla associate with different Ceratobasidium lineages at Valle del Cauca, Colombia. Acta Botanica Brasilica 29:40-44.

Wang, Z., Johnston, P.R., Takamatsu, S., et al. 2006a. Toward a phylogenetic classification of the Leotiomycetes based on rDNA data. Mycologia 98:1065-1075.

Wang, Z., Binder, M., Schoch, C.L., Johnston, P.R., Spatafora, J.W., Hibbett, D.S. 2006b. Evolution of helotialean fungi (Leotiomycetes,
Pezizomycotina): a nuclear rDNA phylogeny. Molecular Phylogenetics and Evolution 41:295-312.

Waud, M., Busschaert, P., Lievens, B., Jacquemyn, H. 2016. Specificity and localised distribution of mycorrhizal fungi in the soil may contribute to co-existence of orchid species. Fungal Ecology 20:155-165.

Weiss, M., Selosse, M., Rexer, K., Urban, A., Oberwinkler, F. 2004. Sebacinales: a hitherto overlooked cosm of heterobasidiomycetes with a broad mycorrhizal potential. Mycological Research 108(9): 1003-1010.

Weiß, M., Waller, F., Zuccaro, A., Selosse, M. 2016. Sebacinales - one thousand and one interactions with land plants. New Phytologist 211: $20-40$.

White, T.J., Bruns, T.D., Lee, S., Taylor, J. 1990. Amplification and direct sequencing of fungal ribosomal RNA genes for phylogenetics. In: Innis MA, Gelfand DH, Sninsky JJ, White TJ (eds) PCR Protocols: a guide to methods and applications. San Diego: Academic Press.

Yeh, C., Chung, K., Liang, C., Tsai, W. 2019. New Insights into the Symbiotic Relationship between Orchids and Fungi. Applied Sciences 9: 585 .

Zhang, N., Castlebury, L.A., Miller, A.N. et al. 2006. An overview of the systematics of the Sordariomycetes based on a four-gene phylogeny. Mycologia 98:1076-1087. 